\title{
Distribution of Phoma sclerotioides on Alfalfa and Winter Wheat Crops in the North Central United States
}

J. E. Larsen, Department of Plant Pathology, University of Minnesota, St. Paul 55108; C. R. Hollingsworth, Northwest Research and Outreach Center and Department of Plant Pathology, University of Minnesota, Crookston 56716; J. Flor, Department of Plant Pathology, University of Minnesota, St. Paul 55108; M. R. Dornbusch, USDAARS-Plant Science Research, Department of Plant Pathology, University of Minnesota, St. Paul 55108; N. L. Simpson, Fort Valley State University, Fort Valley, GA 31030; and D. A. Samac, USDA-ARS-Plant Science Research, Department of Plant Pathology, University of Minnesota, St. Paul 55108

\begin{abstract}
Larsen, J. E., Hollingsworth, C. R., Flor, J., Dornbusch, M. R., Simpson, N. L., and Samac, D. A. 2007. Distribution of Phoma sclerotioides on alfalfa and winter wheat crops in the North Central United States. Plant Dis. 91:551-558.

Brown root rot of alfalfa (Medicago sativa), caused by Phoma sclerotioides, has been reported in several states in the northern United States and in western Canada. A survey was conducted to determine the distribution of the fungus in Minnesota and Wisconsin. Isolates of the pathogen were recovered from roots of alfalfa, winter wheat, and perennial ryegrass plants. The internal transcribed spacer (ITS) 1, 5.8S, and ITS2 of the rDNA of the isolates from alfalfa and wheat were identical and matched the sequences of a $P$. sclerotioides isolate from Wyoming. The fungus was found to be widespread in both states and was detected in roots of alfalfa plants from 17 counties in Minnesota and 14 counties in Wisconsin using polymerase chain reaction (PCR)based assays. A real-time PCR assay was developed that increased sensitivity of detecting the pathogen from plant tissues and soil. The isolates from alfalfa caused disease on inoculated winter wheat plants. Although the fungus was previously found associated with roots of diseased cereal and turfgrass plants, this is the first demonstration of pathogenicity of $P$. sclerotioides on wheat.
\end{abstract}

Additional keywords: Lolium perenne, Triticum aestivum, winterkill

Brown root rot (BRR) of alfalfa (Medicago sativa L.) is caused by Phoma sclerotioides G. Preuss ex Sacc. (formerly Plenodomus meliloti Dearness \& Sanford). The fungus is a slow-growing plant pathogen and saprophyte endemic to the prairie soils of Canada $(1,17,18)$. The fungus was first studied on forage legumes during the mid-1920s (1). Later, it was identified from diseased plants in the Northwest Territories, Nova Scotia, Alaska, the Yukon, as well as British Columbia, Alberta, Saskatchewan, and Manitoba $(1,19)$. In the 1980s, the fungus was found causing widespread root rot of alfalfa in Alberta (1). Only recently, P. sclerotioides was identified from diseased alfalfa in the contiguous United States. During the spring of 1996, P. sclerotioides was found to be the cause of widespread winterkill of alfalfa in

Corresponding author: D. A. Samac

E-mail: dasamac@umn.edu

Accepted for publication 15 November 2006.

doi:10.1094/PDIS-91-5-0551

This article is in the public domain and not copyrightable. It may be freely reprinted with customary crediting of the source. The American Phytopathological Society, 2007. southwestern Wyoming (3), and was detected on a diseased alfalfa sample by the Montana Plant Disease Clinic (15). The pathogen was later isolated from diseased roots of alfalfa located in eight Wyoming counties $(4,5,9)$ and one Idaho county (8). In the spring of 2003, P. sclerotioides was first identified from diseased alfalfa plants in Minnesota and Wisconsin $(11,16)$. The prevalence of the disease and distribution of $P$. sclerotioides throughout the remainder of the United States, particularly the upper-tier states, is largely unknown. Because optimal growth of the fungus occurs at 10 to $15^{\circ} \mathrm{C}(5,8)$, the disease is suspected to contribute to winterkill in regions where winters are extended. Brown root rot is responsible for winter injury and stand decline of a number of forage legumes including alfalfa, red clover (Trifolium pratense L.), bird's foot-trefoil (Lotus corniculatus L.), alsike clover (Trifolium hybridum L.), sweet clover (Melilotus spp.), and common sainfoin (Onobrychis viciifolia Scop.) (1).

Symptoms of BRR on alfalfa include brown, circular-shaped lesions on taproots and lesions girdling, or banding, smaller lateral or feeder roots. Over time, lesions can coalesce and eventually cause plant death (1). Rot of the upper taproot and lower crown interferes with carbohydrate and protein storage and increases susceptibility of alfalfa plants to winterkill (10).

Hard red winter wheat (Triticum aestivum L.) commonly exhibits widespread winterkill in Minnesota (21). Stand losses from adapted cultivars have been attributed exclusively to weather-related plant stresses. While the potential of P. sclerotioides to cause disease on winter wheat is currently unknown, it is a recognized pathogen on over-wintering turfgrass species (18). Although winter wheat acreage continues to increase in Minnesota, many growers avoid planting the crop because of its risk for winterkill. Winter wheat may be grown in rotation with alfalfa, a known host of P. sclerotioides, so it is critical to determine if it is a host for the fungus so that effective disease management strategies can be implemented.

Polymerase chain reaction (PCR)-based techniques have become widely used for the detection of plant pathogens $(2,13,14)$. Because PCR is specific, sensitive, and rapid, it is ideal for identifying a slowgrowing fungus such as $P$. sclerotioides (12). Real-time PCR is even more sensitive, more efficient, and more effectively quantitative than conventional endpoint PCR $(2,14)$. Recent development of affordable, real-time PCR techniques makes real-time PCR particularly suitable for high throughput detection and quantification of pathogens in plant tissues and soil.

The objectives of this work were to (i) determine the distribution of $P$. sclerotioides in the Upper Midwestern United States by surveying for the pathogen in stands of alfalfa and winter wheat; (ii) determine if $P$. sclerotioides causes root rot of hard red winter wheat; and (iii) develop a sensitive and quantitative real-time PCRbased assay to detect and quantify the density of $P$. sclerotioides in roots of alfalfa, cereal crops, and soil.

\section{MATERIALS AND METHODS}

Isolation of $P$. sclerotioides from alfalfa and winter wheat roots. Between 2003 and 2005, 12 alfalfa plants were collected at random from a total of seven commercial production fields located in Marshall, Pennington, Red Lake, and Polk 
counties in northwest Minnesota and in Otter Tail County in west central Minnesota (84 total plant samples). Stand health and age ranged from excellent (approximately 1-year-old) to severely declining (3-years-old). Collected plants were placed into self-sealing plastic bags and stored at $4^{\circ} \mathrm{C}$ until processed. Roots were rinsed with tap water to remove soil, and tissue isolations were made from discolored roots of plants with symptoms and from randomly selected roots of symptomless plants. Root pieces were disinfected for 3 min in a $10 \%$ sodium hypochlorite solution, rinsed for $3 \mathrm{~min}$ in sterile distilled water, and air-dried for $3 \mathrm{~min}$ on filter paper. The root pieces were then placed on water agar and maintained in a dark incubator at $5^{\circ} \mathrm{C}$ for 4 months. If beaked pycnidia characteristic of $P$. sclerotioides were observed in at least one petri dish, the collection site was considered positive for $P$. sclerotioides. Pure cultures of $P$. sclerotioides were obtained by transferring disinfected pycnidia to potato dextrose agar (PDA) plates.

During the spring of 2004, at least 12 winter wheat plants were collected at random from 22 commercial production fields (264 plants) located in Kittson (eight fields), Roseau (five fields), Marshall (one field), Pennington (one field), Polk (five fields), and Norman (one field) counties located in northwestern Minnesota and Redwood County (one field) located in southwestern Minnesota. In addition, plants from one perennial ryegrass (Lolium perenne L.) seed production field in Roseau County were collected during 2004. Plants were placed into self-sealing plastic bags, stored under refrigeration, and processed as previously described. Disinfested seminal and nodal roots were placed in petri dishes containing sterile water agar. Dishes were maintained in a dark incubator at $5^{\circ} \mathrm{C}$ for at least 2 months. If beaked pycnidia characteristics of $P$. sclerotioides were observed, a pure culture of the fungus was obtained as before. In addition, DNA was extracted from winter wheat and perennial ryegrass samples from each location for detection of $P$. sclerotioides by a PCRbased assay.

Survey for $\boldsymbol{P}$. sclerotioides in alfalfa fields. A survey for $P$. sclerotioides was conducted in alfalfa stands of the Upper Midwest beginning in the fall of 2003 and continuing to fall of 2005. Overall, plants from 265 fields were evaluated. The majority of plants were from Minnesota (113 fields in a total of 38 counties) and Wisconsin (102 fields in 19 counties), with a small number of samples from Iowa (four fields), Illinois (five fields), Idaho (three fields), and Wyoming (four fields), as well as from Ontario (five fields) and Manitoba ( 27 fields). Plants were collected by extension educators, university researchers, producers, and others from commercial production fields and experimental plots.
Plants were collected from healthy and declining stands. From five to 20 plants were removed randomly across fields. At least five plants were assayed by PCR from each location.

In preparation for the PCR assay, DNA was isolated from alfalfa, winter wheat, and perennial ryegrass roots using the Fast DNA kit and Fast Prep instrument (QBIOgene Solon, OH). Approximately 200 $\mathrm{mg}$ of root tissue was homogenized in 500 $\mu \mathrm{l}$ of buffer CLS-Y, $400 \mu \mathrm{l}$ of buffer CLSVF, and $100 \mu \mathrm{l}$ of buffer PPS. Samples were agitated for $30 \mathrm{~s}$ on setting 5. DNA of $P$. sclerotioides was detected using a modified version of a previously established endpoint PCR-based assay specific for $P$. sclerotioides (12). PCR reactions were performed in 25 - $\mu$ l volumes containing 50 ng template DNA, $2.5 \mu \mathrm{l} 10 \times$ reaction buffer (Promega Corp., Madison, WI), 2.5 $\mu \mathrm{d}$ dNTP mixture (2.5 mM each dNTP; TaKaRa Bio Inc., Otsu, Shiga, Japan), 1 $\mu \mathrm{M}$ SCAR primers, and 0.625 units Taq DNA polymerase. Reaction conditions were $2 \mathrm{~min}$ at $95^{\circ} \mathrm{C}$ for one cycle, $1 \mathrm{~min}$ at $94^{\circ} \mathrm{C}, 1 \mathrm{~min}$ at $65^{\circ} \mathrm{C}$, and $1 \mathrm{~min}$ at $72^{\circ} \mathrm{C}$ for 40 cycles, followed by $7 \mathrm{~min}$ at $72^{\circ} \mathrm{C}$ for one cycle. The 499-bp amplicon was detected by agarose gel electrophoresis.

DNA sequence of the rDNA internal transcribed spacers (ITS) and $5.8 S$ rDNA. Isolates of $P$. sclerotioides were grown on PDA plates at $15^{\circ} \mathrm{C}$ for 5 weeks. Isolates of $P$. medicaginis and $P$. pinodella were grown on PDA plates at $25^{\circ} \mathrm{C}$ for 3 weeks. DNA was extracted from mycelium and spores scraped from the surface of plates using the Q-BIOgene FastDNA kit as per the manufacturer's protocol for fungal DNA. The ITS regions of all samples were PCR amplified with the universal primer pair ITS1 5'-TCCGTAGGT GAACCTGCGG-3' and ITS4 5'-TCC TCCGCTTATTGATATGC-3' (20). PCR reactions were performed in $50-\mu$ l reactions containing $100 \mathrm{ng}$ of template DNA, $5 \mu \mathrm{l} 10 \times$ ThermoPol PCR buffer (New England Biolabs, Beverly, MA), $5 \mu \mathrm{dNTP}$ mixture $(2.5 \mathrm{mM}$ each dNTP; TaKaRa Bio), $50 \mathrm{ng}$ each oligonucleotide primer, and 5 units Taq DNA polymerase. Thermocycling conditions consisted of an initial denaturing step at $94^{\circ} \mathrm{C}$ for $2 \mathrm{~min}$, followed by 30 cycles of $94^{\circ} \mathrm{C}$ for $30 \mathrm{~s}$, $55^{\circ} \mathrm{C}$ for $1 \mathrm{~min}$, and $72^{\circ} \mathrm{C}$ for $1 \mathrm{~min}$, and a final extension of $72^{\circ} \mathrm{C}$ for $7 \mathrm{~min}$. Verification of amplification was done by UV illumination in a $1 \%$ agarose gel after electrophoresis in the presence of ethidium bromide.

For cloning, PCR products were purified from the gel using the QIAquick Gel Extraction Kit (Qiagen Inc., Valencia, CA). The fragments were ligated into vector pGEM-T II (Promega Corp.) and transformed into competent cells of $E$. coli according to the manufacturer's instructions. Plasmids were isolated using the Qiaprep Spin Miniprep Kit (Qiagen).
Samples were sequenced by the Advanced Genetic Analysis Center (University of Minnesota) with primers ITS1 or ITS4. Sequences were aligned using ClustalW (1.83) Multiple Sequence Alignment.

Inoculation of winter wheat with $\boldsymbol{P}$. sclerotioides. On 4 October 2004, cultivar Jerry hard red winter wheat seed were planted into Deepot Cells (Stuewe and Sons, Inc., Corvallis, OR) containing a pasteurized native soil:sand mixture (1:1) at a depth of $2.54 \mathrm{~cm}$. Plants were maintained in the greenhouse at $10^{\circ} \mathrm{C}\left( \pm 5^{\circ} \mathrm{C}\right)$ under natural lighting for 7 days. A total of 125 potted test plants were situated in Deepot support trays (Stuewe and Sons).

Inoculum was prepared using a modified protocol (7) from four $P$. sclerotioides isolates obtained from diseased alfalfa roots from four locations in Minnesota during 2004 (Thief River Falls [TRF], Red Lake Falls [RLF], Holt, and Fergus Falls $[F F])$. Sterile barley grains were placed into five self-sealing plastic bags and inoculated with one each $P$. sclerotioides isolate. One bag of noninoculated sterile grain was used as the nontreated control treatment. Sealed bags were maintained in a dark growth chamber at $5^{\circ} \mathrm{C}$ where they were massaged periodically to increase colonization of the fungus on the substrate.

Plants were placed outside on 11 October 2004, and pots were situated above the soil surface at the University of Minnesota Northwest Research and Outreach Center, Crookston, MN. The lower portion (sides and bottom) of each group of 25 pots was isolated from other pots by placing a plastic 189-liter bag around pots. The top edge of each bag was pulled upward through pot support openings in trays before pots were inserted. Pots were positioned snugly into perimeter tray support openings, securing the plastic barrier in place. This primarily was done to reduce wind penetration of cold air and prevent possible crosscontamination between $P$. sclerotioides isolates. The test was then surrounded snugly by a wheat straw bale perimeter, and loose straw was forced between racks and inserted into openings to reduce air circulation during the winter. The test was watered during the fall as needed to promote plant establishment and growth.

On 26 October, when plants were 20 days old, three holes approximately 2.54 $\mathrm{cm}$ deep were made in the soil in each pot. Holes were placed midway between the seedling and the pot wall (approximately 1 $\mathrm{cm}$ from the seedling). One barley grain was dropped into each hole and the soil was pinched closed. In total, soil surrounding each test plant contained either three sterile barley grains or three grains infested with one of the four isolates of P. sclerotioides (total of 25 pots each).

After more than 6 months outside, trays of potted plants were returned to the greenhouse on 29 April 2005. Plants were maintained in the greenhouse for 2 weeks 
until roots could be examined microscopically for pathogen signs and disease symptoms. Root tissues of live plants, regardless of symptom expression, were processed 17 May 2005 to complete Koch's postulates. Tissues were disinfected as described above and placed into petri dishes containing sterile water agar. Dishes were maintained in a dark incubator at $5^{\circ} \mathrm{C}$ for more than 4 months. Dishes were examined on 27 September for beaked pycnidial production. If present, pycnidia were surfacedisinfected for $30 \mathrm{~s}$ in a $10 \%$ sodium hypochlorite solution, rinsed for $30 \mathrm{~s}$ in sterile distilled water, and placed in dishes containing PDA. Pure cultures were examined and compared with original cultures of $P$. sclerotioides.

Real-time PCR assay. PCR reactions were carried out using SYBR Green Supermixes with ROX (Bio-Rad Laboratories, Inc., Hercules, CA). Primers for realtime PCR (forward primer 5'-CCTGAA GCCGTCCAAGTT-3', reverse primer 5'GCTCACCGAACACGAGCTTT-3') were designed using Primer Express Software (Applied Biosystems, Foster City, CA) and were selected within the sequence of the target gene amplicon (499 bp) for the conventional endpoint PCR assay (12). The real-time amplicon was designed to be 130 bp (from bp 253 to bp 372 of the 499-bp amplicon). Each PCR reaction was $25 \mu \mathrm{l}$ total volume with primers at a concentration of $50 \mathrm{nM}$. Real-time PCR detection was conducted using the ABI Prism 7000 Sequence Detection System (Applied Biosystems). The reaction was incubated at $50^{\circ} \mathrm{C}$ for $2 \mathrm{~min}$ and $95^{\circ} \mathrm{C}$ for $3 \mathrm{~min}$ followed by 40 cycles of $15 \mathrm{~s}$ at $95^{\circ} \mathrm{C}$ and 1 min at $60^{\circ} \mathrm{C}$. Melting curve analysis was conducted according to the ABI software. Standard curves were constructed using dilutions of gel-purified PCR amplicon (499 bp) generated by the endpoint PCR reaction. Copy number for the target gene was determined based on DNA concentration of the gel-purified PCR amplicon. A dilution series of standard DNA was included to generate a standard curve for each experimental plate. Cycle threshold (Ct) values for PCR standards were not affected when the standards were measured in a background of up to $35 \mathrm{ng}$ alfalfa root DNA. Each sample was amplified in triplicate.

Standard curves were also constructed using 10-fold dilutions of purified $P$. sclerotioides DNA. A linear relationship existed between $\mathrm{Ct}$ values and the logarithm of starting DNA concentration for a range of concentrations between $1.5 \mathrm{pg}$ and 1.5 ng of purified $P$. sclerotioides DNA. Ct values generated by real-time PCR analysis of 100 to 100,000 starting copies of the conventional PCR amplicon roughly corresponded to $\mathrm{Ct}$ values generated by $1.5 \mathrm{pg}$ to $1.5 \mathrm{ng}$ of purified P. sclerotioides DNA, respectively. As the gel-purified DNA amplicon provided a greater range of linear values than the purified $P$. sclerotioides DNA, the gel-purified PCR amplicon was used to develop the real-time PCR assay.

Soil DNA extraction. Spores from $P$. sclerotioides cultures grown on PDA plates were suspended in sterile distilled water and counted with a hemacytometer. Tenfold dilutions were prepared and added to 250-mg samples of uninfested soil collected from fields at the University of Minnesota Experiment Station, St. Paul, MN. Total DNA was prepared from soil using the Power Soil DNA extraction kit (Mo Bio Laboratories, Carlsbad, CA).

\section{RESULTS}

Distribution of $P$. sclerotioides on alfalfa in Minnesota and Wisconsin. Pure cultures of $P$. sclerotioides were obtained from alfalfa plants from five locations (Table 1). They originated from production fields in Pennington County (TRF), Red Lake County (RLF), Otter Tail County (FF), Polk County (Bratvold), and Marshall County (Holt). In vitro, the cultures had beaked pycnidia characteristic of $P$. sclerotioides and produced single-celled hyaline elliptical conidia.

The DNA sequence from the ITS1, 5.8S, and ITS2 of the nuclear rDNA of isolates from alfalfa plants from Minnesota were compared with the sequence from $P$. sclerotioides isolates originating from Canada (ATCC 56515) and Wyoming (ATCC MYA295) as well as to type cultures of $P$. medicaginis (ATCC 52798), which causes spring black stem and leaf spot of alfalfa, and $P$. pinodella (ATCC 32162), the causal agent of Ascochyta foot rot and black stem of pea. Sequences from all isolates were deposited in GenBank (Table 1). The length of the sequences from $P$. sclerotioides ATCC 56515, P. medicaginis ATCC 52798, and $P$. pinodella ATCC 32162 were 436, 430, and $431 \mathrm{bp}$, respectively. The $P$. sclerotioides isolate from
Wyoming and the isolates from Minnesota were identical in sequence and differed from isolate ATCC 56515 from Canada by three base changes, all in the ITS2 sequence. In contrast, six indels and 59 base changes were observed between the sequence from $P$. sclerotioides ATCC 56515 and $P$. medicaginis ATCC52798, and nine indels and 63 base changes between $P$. sclerotioides ATCC 56515 and $P$. pinodella ATCC 32162. A BLASTn search of GenBank with the $P$. sclerotioides sequence found the closest matching sequence $(95 \%$ identity) was to the corresponding rDNA from Leptosphaeria doliolum (anamorph Phoma hoehnelii).

To rapidly detect $P$. sclerotioides in plant samples, we used a modified version of a conventional endpoint PCR-based assay previously shown to be specific for the fungus (12). Amplicons of the expected size (499 bp) were generated from the DNA of numerous alfalfa roots that were sampled. Test amplicons co-migrated with amplicons generated by PCR of purified $P$. sclerotioides DNA. The fungus was identified in alfalfa samples taken from sites in Minnesota, Wisconsin, Idaho, and Wyoming, but not in alfalfa samples taken from fields in Iowa, Illinois, Ontario, or Manitoba. In Minnesota and Wisconsin, the fungus was found to be relatively widespread. About one-third (21 out of 57) of the counties surveyed had at least one field in which plants tested positive for the fungus by the endpoint PCR assay (Table 2). In Minnesota and Wisconsin, the fungus appeared concentrated in three main regions: the Red River Valley in northwestern Minnesota, the St. Croix River Valley in Minnesota and Wisconsin, and west of Green Bay in northeastern Wisconsin (Fig. 1). The fungus was detected in alfalfa roots with brown necrotic lesions and also from alfalfa roots asymptomatic for BRR. Plants positive for the fungus originated from

Table 1. Cultures of Phoma species, host, place of origin, and GenBank accession numbers of DNA sequence for the ITS1, 5.8S, and ITS2 regions of the rDNA

\begin{tabular}{|c|c|c|c|c|c|}
\hline $\begin{array}{l}\text { Isolate } \\
\text { designation }^{\mathrm{a}}\end{array}$ & Source & Phoma species & Host & Origin & $\begin{array}{l}\text { GenBank } \\
\text { accession } \\
\text { number }\end{array}$ \\
\hline 56515 & $\mathrm{ATCC}^{\mathrm{b}}$ & P. sclerotioides & Alfalfa & Canada & DQ525733 \\
\hline MYA295 & ATCC & P. sclerotioides & Alfalfa & Wyoming & DQ530443 \\
\hline 52798 & ATCC & P. medicaginis & Alfalfa & South Dakota & DQ525735 \\
\hline 32162 & ATCC & P. pinodella & Pea & Netherlands & DQ525734 \\
\hline TRF & Field & P. sclerotioides & Alfalfa & Minnesota & DQ530444 \\
\hline Bratvold & Field & P. sclerotioides & Alfalfa & Minnesota & DQ530449 \\
\hline RLF & Field & P. sclerotioides & Alfalfa & Minnesota & DQ530450 \\
\hline FF & Field & P. sclerotioides & Alfalfa & Minnesota & DQ530451 \\
\hline Holt & Field & P. sclerotioides & Alfalfa & Minnesota & DQ530452 \\
\hline Roosevelt & Field & P. sclerotioides & Perennial ryegrass & Minnesota & DQ530444 \\
\hline Roseau & Field & P. sclerotioides & Winter wheat & Minnesota & DQ530446 \\
\hline Hallock & Field & P. sclerotioides & Winter wheat & Minnesota & DQ530447 \\
\hline Oslo & Field & P. sclerotioides & Winter wheat & Minnesota & DQ530448 \\
\hline
\end{tabular}

a TRF, isolate from near Thief River Falls, MN; Bratvold, isolate from near Crookston, MN; RLF, isolate from near Red Lake Falls, MN; FF, isolate from near Fergus Falls, MN; Roosevelt, isolate from near Roosevelt, MN; Roseau, isolate from near Roseau, MN; Hallock, isolate from near Hallock, MN; Oslo, isolate from near Oslo, MN.

b American Type Culture Collection. 
both younger (2-year-old) and older (3- to 11-year-old) stands. In some, but not all, cases the presence of the fungus was associated with winter injury and/or stand decline.

Identification of $\boldsymbol{P}$. sclerotioides from winter wheat and perennial ryegrass. Winter wheat plants from 22 locations in Minnesota were assayed for $P$. sclerotioides with the endpoint $\mathrm{PCR}$ test and root tissue isolations made. Plants from a site in Kittson County and Marshall County were positive by PCR. Pure cultures of $P$. sclerotioides with characteristic beaked pycnidia were obtained from plants from Marshall County (Oslo), Kittson County (Hallock), and Roseau County (Roseau) (Table 1). In addition, an isolate was obtained from perennial ryegrass from Roseau County (Roosevelt). DNA sequencing of the ITS1, 5.8S, and ITS2 of the rDNA was performed for the wheat and perennial ryegrass isolates. The sequences were identical to the sequences obtained from alfalfa in Minnesota except for a single base deletion in the Roosevelt perennial ryegrass isolate in the ITS2 region.

Real-time PCR-based assay. To further assess the presence of $P$. sclerotioides in plant roots and surrounding soil, we developed a more sensitive, quantitative assay based on real-time PCR. Primers for the real-time PCR assay were selected from the DNA sequence amplified in the conventional endpoint PCR assay (12). A standard curve was constructed by plotting average threshold cycles ( $\mathrm{Ct}$ values) for 10-fold dilutions of the conventional PCR amplicon versus the logarithm of the starting copy number for each dilution of the conventional endpoint PCR amplicon (Fig. 2). The standard curve showed a linear relationship between $\mathrm{Ct}$ values and the logarithm of the starting template copy number. The assay was quantitative and reproducible over a wide range of concentrations, greater than five orders of magnitude. The assay readily detected as few as
10 copies of the $P$. sclerotioides target gene. For all experiments, the linear coefficient of the standard curve was $R^{2}=0.97$ to 0.99 and the slope of the curve was in a range corresponding to 90 to $100 \%$ efficiency for the PCR reaction. Nonspecific amplification was not observed by either gel electrophoresis of the PCR product or melting curve analysis, confirming the specificity of the assay design.

Alfalfa DNA samples from the survey conducted in 2005 were re-analyzed using the real-time PCR assay. The amount of $P$. sclerotioides DNA in each sample was quantified by comparing the average $\mathrm{Ct}$ values for the alfalfa sample with $\mathrm{Ct}$ values on the standard curve. Samples identified positive by the conventional endpoint PCR assay were confirmed positive by the realtime PCR assay. As for the conventional assay, the real-time PCR assay did not detect $P$. sclerotioides in the DNA of healthy, uninfected alfalfa plants propagated in the greenhouse (data not shown).

Table 2. Total survey of alfalfa fields in the United States and Canada for Phoma sclerotioides on alfalfa roots using endpoint polymerase chain reaction $(\mathrm{PCR})^{\mathrm{a}}$

\begin{tabular}{|c|c|c|c|c|c|c|c|}
\hline State & County & $\begin{array}{c}\text { Number of } \\
\text { fields sampled }\end{array}$ & $\begin{array}{c}\begin{array}{c}\text { Number of } \\
\text { positive fields }\end{array} \\
\end{array}$ & $\begin{array}{l}\text { State/ } \\
\text { province }\end{array}$ & County & $\begin{array}{c}\text { Number of } \\
\text { fields sampled }\end{array}$ & $\begin{array}{c}\begin{array}{c}\text { Number of } \\
\text { positive fields }\end{array} \\
\end{array}$ \\
\hline $\mathrm{MN}$ & Aitkin & 4 & 0 & WI & Chippewa & 6 & 1 \\
\hline MN & Benton & 5 & 1 & WI & Columbia & 3 & 1 \\
\hline $\mathrm{MN}$ & Big Stone & 1 & 0 & WI & Dunn & 1 & 1 \\
\hline MN & Carver & 4 & 0 & WI & Eau Claire & 4 & 0 \\
\hline $\mathrm{MN}$ & Cass & 2 & 1 & WI & Fond du Lac & 4 & 0 \\
\hline MN & Cottonwood & 1 & 0 & WI & Grant & 3 & 0 \\
\hline MN & Dakota & 4 & 0 & WI & Juneau & 1 & 0 \\
\hline MN & Dodge & 3 & 0 & WI & Lafayette & 1 & 0 \\
\hline MN & Fillmore & 3 & 0 & WI & Manitowoc & 3 & 0 \\
\hline $\mathrm{MN}$ & Freeborn & 1 & 0 & WI & Marinette & 1 & 1 \\
\hline MN & Goodhue & 1 & 1 & WI & Monroe & 8 & 0 \\
\hline MN & Hennepin & 1 & 0 & WI & Oconto & 1 & 1 \\
\hline MN & Isanti & 1 & 0 & WI & Pierce & 3 & 1 \\
\hline MN & Itasca & 5 & 0 & WI & Polk & 3 & 0 \\
\hline MN & Kandiyohi & 1 & 0 & WI & Rock & 2 & 0 \\
\hline MN & Marshall & 3 & 1 & WI & Shawano & 19 & 1 \\
\hline $\mathrm{MN}$ & Martin & 1 & 0 & WI & St. Croix & 28 & 6 \\
\hline MN & McLeod & 1 & 0 & WI & Washburn & 5 & 0 \\
\hline MN & Meeker & 2 & 0 & WI & Waupaca & 6 & 0 \\
\hline MN & Morisson & 3 & 0 & Total & & 102 & 13 \\
\hline $\mathrm{MN}$ & Mower & 2 & 0 & & & & \\
\hline $\mathrm{MN}$ & Murray & 3 & 0 & ID & Fairfield & 3 & 2 \\
\hline MN & Nobles & 3 & 0 & & & & \\
\hline $\mathrm{MN}$ & Olmsted & 1 & 0 & WY & Goshen & 2 & 1 \\
\hline MN & Otter Tail & 6 & 1 & WY & Natrona & 2 & 2 \\
\hline MN & Pennington & 3 & 2 & Total & & 4 & 3 \\
\hline MN & Pipestone & 3 & 0 & & & & \\
\hline MN & Polk & 1 & 1 & $\mathrm{IL}$ & Champaign & 2 & 0 \\
\hline MN & Red Lake & 10 & 2 & $\mathrm{IL}$ & Carroll & 1 & 0 \\
\hline MN & Rock & 1 & 1 & $\mathrm{IL}$ & Kane & 1 & 0 \\
\hline $\mathrm{MN}$ & Sherburne & 2 & 1 & $\mathrm{IL}$ & Bureau & 1 & 0 \\
\hline $\mathrm{MN}$ & Sibley & 2 & 0 & Total & & 5 & 0 \\
\hline $\mathrm{MN}$ & Stearns & 3 & 0 & & & & \\
\hline MN & Steele & 3 & 0 & IA & Polk & 1 & 0 \\
\hline MN & Wabasha & 5 & 1 & IA & Not identified & 4 & 0 \\
\hline MN & Washington & 3 & 1 & IA & Boone & 1 & 0 \\
\hline $\mathrm{MN}$ & Winona & 13 & 2 & Total & & 6 & 0 \\
\hline $\mathrm{MN}$ & Wright & 2 & 0 & & & & \\
\hline \multirow[t]{3}{*}{ Total } & & 113 & 16 & ONT & & 5 & 0 \\
\hline & & & & MB & & 27 & 0 \\
\hline & & & & Grand total & & 265 & 34 \\
\hline
\end{tabular}

${ }^{\text {a }}$ Five to 20 plants were collected randomly from each field. At least five plants were assayed from each field.

${ }^{\mathrm{b}}$ A field was considered positive for $P$. sclerotioides if at least one root DNA sample from collected plants yielded a 499-bp product by the endpoint PCR assay. 
However, the more sensitive real-time assay identified $P$. sclerotioides DNA in alfalfa samples that were negative by the conventional endpoint PCR assay. In the plants sampled in 2005, six out of 53 fields (in four out of 20 counties) tested positive using conventional endpoint PCR, whereas 51 out of 53 fields (in 18 out of 20 counties) tested positive using real-time PCR (Table 3). The real-time PCR assay also detected low levels of $P$. sclerotioides in plants from 22 out of 27 sites in Manitoba, just north of the Red River Valley, which had tested negative by the endpoint PCR assay (data not shown). The relative amount of $P$. sclerotioides in alfalfa roots determined by real-time PCR was evaluated according to the calculated starting copy number of the target gene for each sample. Root DNA samples with 10 to 100 calculated copies of the target gene were considered to have very low amounts of the fungus, whereas $>100$ to 1,000 copies was considered a low level, $>1,000$ to 10,000 copies was considered a moderate level, and $>10,000$ copies was considered a high level. Generally, only root DNA samples with high amounts of the fungus as measured by the real-time PCR assay were identified as positive by conventional endpoint PCR and by isolation of the fungus from roots.

DNA was prepared from soil samples spiked with conidia from $P$. sclerotioides cultures. Figure 3A shows a linear relationship between the number of spores in the spiked samples and the number of copies of the target gene determined by real-time PCR over a wide range of starting concentrations. The real-time assay was able to reproducibly detect as few as 25 copies of the target gene per sample, or the equivalent of 1,000 copies per $100 \mathrm{mg}$ of soil. DNA of P. sclerotioides was effectively detected in a background of total DNA extracted from the soil, and the calculated spore number based on real-time PCR was close to the predicted spore number for $100 \%$ DNA recovery and amplification (Fig. 3B). Preliminary studies with the real-time PCR assay identified $P$. sclerotioides in the soil of alfalfa fields in Otter Tail and Stearns counties of Minnesota, where the fungus was identified in the roots of alfalfa plants by conventional endpoint PCR (data not shown).

Alfalfa isolates of $\boldsymbol{P}$. sclerotioides cause root rot on winter wheat. Daily weather information was collected manually less than $1 \mathrm{~km}$ from the test site. Monthly air temperature lows for the 2004-2005 winter exposure period were: $-3.3^{\circ} \mathrm{C}$, Oct.; $-15.5^{\circ} \mathrm{C}$, Nov.; $-26.6^{\circ} \mathrm{C}$, Dec.; $-37.7^{\circ} \mathrm{C}$, Jan.; $-26.1^{\circ} \mathrm{C}$, Feb.; $-20.5^{\circ} \mathrm{C}$, Mar.; and $-4.4^{\circ} \mathrm{C}$, April. During January, low daily

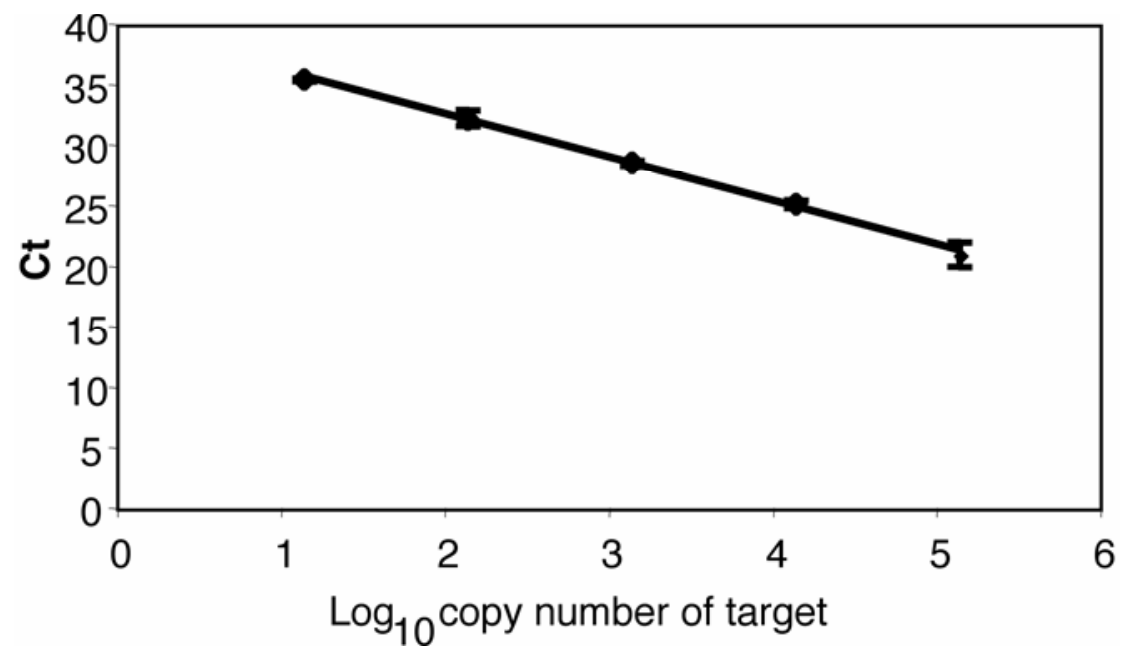

Fig. 2. Real-time polymerase chain reaction (PCR) standard curve for Phoma sclerotioides. Three replicate PCR reactions were performed for each quantity $\left(1.4 \times 10^{1}\right.$ to $1.4 \times 10^{5}$ copies $)$ of target DNA. Error bars represent one standard deviation.

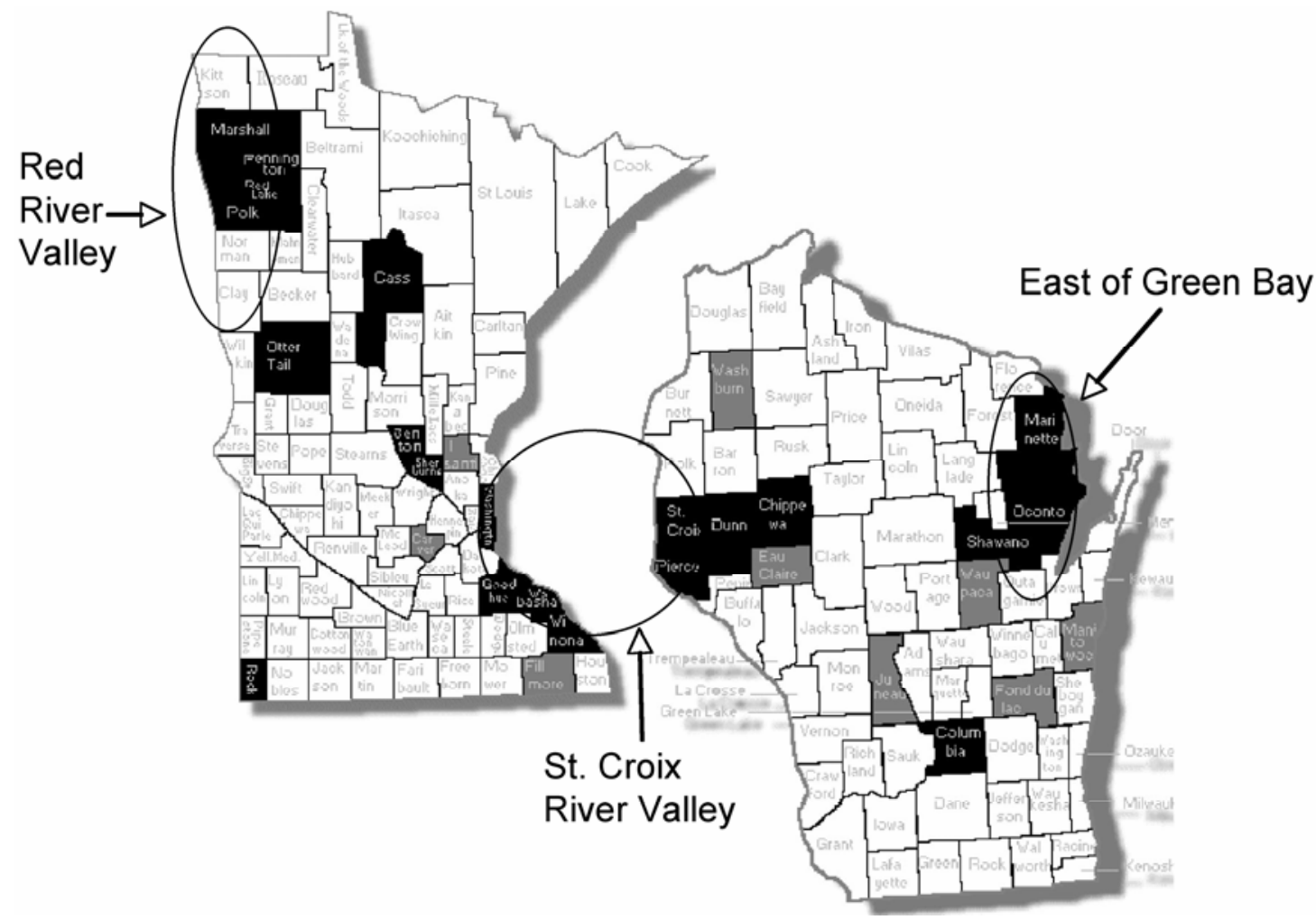

Fig. 1. Counties in Minnesota (left) and Wisconsin (right) in which Phoma sclerotioides was identified in alfalfa plants. Counties in which positive plants were identified by real-time polymerase chain reaction (PCR) (gray) and by both real-time PCR and endpoint PCR (black). 
air temperatures were bitter cold for 17 nonconsecutive days, ranging between $-23.3^{\circ} \mathrm{C}$ and $-38^{\circ} \mathrm{C}$. January high daily air temperatures remained in the negative digits for 29 of 31 days. Thirty-eight percent (47 plants) of test plants died during the winter exposure period from environmental stresses unrelated to disease (Table 4). These plants did not have symptoms of root or crown rot disease. In addition, seven plants were not recoverable. It is likely that missing plants were eaten by rabbits or migrating geese. Fifty plants (40\%) were killed during the winter and had pycnidia characteristic of $P$. sclerotioides attached to roots that were brown and rotted. A total of 21 plants were alive in May of 2005, nine from the noninoculated control treatment and 12 from inoculated treatments. Of the 100 inoculated plants, four had neither signs of $P$. sclerotioides nor root rot symptoms. The remaining eight live plants from inoculated treatments had pycnidia embedded or superficially attached to partially rotted root systems. All plants were either killed or missing from the Holt isolate treatment, while as many as five plants remained alive but colonized by the RLF isolate (Table 4). P. sclerotioides was identified from pure cultures using colony, pycnidia, and spore morphologies.

\section{DISCUSSION}

A 3-year survey for P. sclerotioides, primarily in Minnesota and Wisconsin, found the fungus to be widespread in both states on alfalfa roots. Although the fungus has been recognized as the cause of BRR of alfalfa for many years (1), diagnosis of BRR was difficult due to the slow growth of the pathogen in culture. Development of a PCR assay specific for $P$. sclerotioides (12) made diagnosis more rapid and has facilitated testing of plants from numerous locations. The high frequency of identification of the fungus in several areas, such as the Red River Valley of Minnesota, suggests that certain locations may be more favorable for pathogen survival and plant infection. It is possible that the fungus is widespread in the northern tier states of the United States and the Prairie Provinces of Canada (3). Surveys in additional locations are needed to determine the complete range of the fungus. The survey showed that in some but not all cases, the fungus was associated with alfalfa plants suffering stand decline or winter injury. Due to the slow growth of the fungus, symptoms may take three or more winter seasons to become apparent (17), although under conducive environmental conditions disease can occur after one winter $(6,7)$. Both environmental and biotic factors may contribute to winter injury and winterkill of alfalfa. At locations in which the fungus is present and in years when the environment supports disease development, BRR is likely a primary cause of plant death. However, the disease may be overlooked much of the time.

$P$. sclerotioides was identified on roots of both winter wheat and perennial ryegrass. Previously, the fungus was identified in association with monocots (18); how- ever, pathogenicity had not been demonstrated. In this study, isolates of $P$. sclerotioides from alfalfa were used to inoculate roots of hard red winter wheat plants in the fall and disease was assessed the following spring. Although there was a high frequency of mortality in the noninoculated plants, mortality was higher in inoculated plants, and a large proportion of these plants had pycnidia of $P$. sclerotioides in rotted roots. From this evidence we conclude that the fungus is a pathogen of winter wheat and causes root rot, which likely contributes to winterkill of plants in the field. These results support the current recommendations for management of BRR, which include rotation to annual crops. Additional studies are needed to validate these preliminary findings.

The isolates causing disease on alfalfa in Minnesota were confirmed to be $P$. sclerotioides by sequencing the ITS $1,5.8 \mathrm{~S}$, and ITS 2 of the nuclear rDNA. The sequences from the Minnesota isolates were identical to the isolate from Wyoming. In addition, isolates from winter wheat had the same sequence as the alfalfa isolates. Interestingly, the isolate from perennial ryegrass had a single base deletion in the ITS2 region. Additional isolates from ryegrass are needed to determine the incidence of this variant. The alfalfa and wheat isolates differ from the $P$. sclerotioides isolate from Canada by three base changes in the ITS2 region. This suggests that there may be regionally distinct populations of the fungus.

Table 3. Comparing the identification of Phoma sclerotioides in alfalfa roots from plants collected in 2005 using real-time polymerase chain reaction (PCR) versus endpoint PCR $^{\mathrm{a}}$

\begin{tabular}{|c|c|c|c|c|c|}
\hline State & County & $\begin{array}{l}\text { Number of } \\
\text { fields sampled }\end{array}$ & $\begin{array}{c}\text { Number of positive } \\
\text { fields by endpoint PCR }\end{array}$ & $\begin{array}{l}\text { Number of positive } \\
\text { fields by real-time PCR }\end{array}$ & $\begin{array}{l}\text { Relative level of } P \text {. sclerotioides } \\
\text { assessed by real-time } \text { PCR }^{\mathrm{d}}\end{array}$ \\
\hline MN & Benton & 3 & 0 & 3 & Low-moderate \\
\hline MN & Carver & 1 & 1 & 1 & Moderate \\
\hline MN & Fillmore & 1 & 0 & 1 & Low-moderate \\
\hline MN & Goodhue & 1 & 1 & 1 & Moderate \\
\hline $\mathrm{MN}$ & Hennepin & 1 & 0 & 0 & Not detected \\
\hline MN & Isanti & 1 & 0 & 1 & Moderate \\
\hline MN & Otter Tail & 1 & 0 & 1 & Moderate \\
\hline MN & Sherburne & 1 & 0 & 1 & Very low \\
\hline MN & Stearns & 4 & 0 & 4 & Low-moderate \\
\hline $\mathrm{MN}$ & Winona & 8 & 0 & 7 & Very low-moderate \\
\hline Total & & 22 & 2 & 20 & \\
\hline WI & Dunn & 1 & 1 & 1 & High \\
\hline WI & Eau Claire & 1 & 0 & 1 & Moderate \\
\hline WI & Fond du Lac & 4 & 0 & 3 & Very low-moderate \\
\hline WI & Juneau & 1 & 0 & 1 & Low \\
\hline WI & Manitowoc & 3 & 0 & 3 & Very low \\
\hline WI & Pierce & 1 & 0 & 1 & Low \\
\hline WI & Shawano & 1 & 0 & 0 & Not detected \\
\hline WI & St. Croix & 13 & 3 & 13 & Low-moderate \\
\hline WI & Washburn & 5 & 0 & 5 & Very low-low \\
\hline WI & Waupaca & 1 & 0 & 1 & Very low \\
\hline Total & & 31 & 4 & 29 & \\
\hline
\end{tabular}

a Five to 20 plants were collected randomly from each field. At least five plants were assayed from each field. DNA samples from roots of collected plants were assayed by the endpoint and real-time PCR assays.

b A field was considered positive for P. sclerotioides if at least one root DNA sample from collected plants yielded a 499-bp product by the endpoint PCR assay.

c A field was considered positive if at least one root DNA sample from collected plants had $>100$ calculated copies of the target gene.

d Very low $=10$ to 100 calculated copies of the target gene; low $=>100$ to 1,000 copies; moderate $=>1,000$ to 10,000 copies; high $=>10,000$ copies . 
A real-time PCR assay for $P$. sclerotioides was developed to increase the sensitivity of detection and to be able to quantify fungal material in plant and soil samples. A sensitive assay is needed for detection of the pathogen in soil, as the amount of the fungus in individual samples can be low. Although the real-time PCR assay can detect as few as 10 copies of the target gene, approximately 100 copies are reproducibly detected in DNA extracted from alfalfa roots. Reproducible detection

A

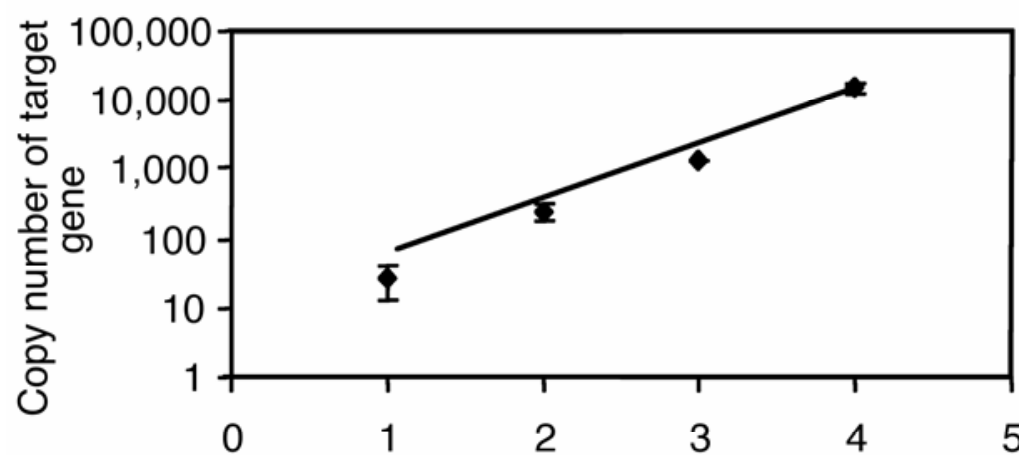

$\log _{10}$ starting spore number

B

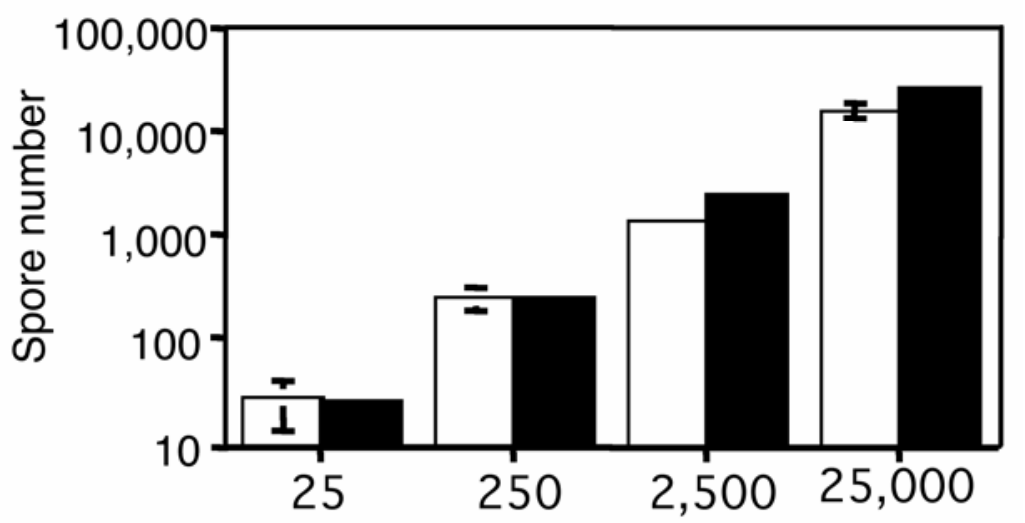

Spiked samples

Fig. 3. Real-time polymerase chain reaction (PCR) quantitation of Phoma sclerotioides in soil samples. Soil samples $(250 \mathrm{mg})$ were spiked with known quantities $\left(2.5 \times 10^{3}\right.$ to $\left.2.5 \times 10^{6}\right)$ of $P$. sclerotioides conidia. A, Target gene copy number increases in a linear fashion with increasing numbers of spores added to soil. Efficiency of PCR amplification $=90 \%, R^{2}=0.98$. B, Open bars represent calculated spore number based on real-time PCR, whereas solid bars represent predicted spore number for $100 \%$ DNA recovery and 100\% efficiency of PCR. Error bars represent standard deviation for triplicate reactions.

Table 4. Percent mortality following a winter exposure period of hard red winter wheat plants inoculated with one of four Phoma sclerotioides isolates from alfalfa during fall 2004

\begin{tabular}{|c|c|c|c|c|c|}
\hline \multirow[b]{2}{*}{ Treatment $^{\mathbf{a}}$} & \multicolumn{2}{|c|}{ Live plants (\%) } & \multicolumn{2}{|c|}{ Plant mortality $(\%)$} & \multirow{2}{*}{$\begin{array}{c}\text { Missing } \\
\text { plants }(\%)\end{array}$} \\
\hline & Ps $(+)^{b}$ & Ps (-) & Ps (+) & Ps (-) & \\
\hline $\begin{array}{l}\text { Noninoculated control } \\
\text { Inoculated }\end{array}$ & 0 & 36 & 0 & 64 & \\
\hline TRF isolate $\mathrm{c}^{\mathrm{c}}$ & 8 & 8 & 44 & 28 & 12 \\
\hline RLF isolate & 8 & 8 & 64 & 8 & \\
\hline Holt isolate & 0 & 0 & 40 & 60 & \\
\hline FF isolate & 4 & 0 & 52 & 28 & 16 \\
\hline
\end{tabular}

${ }^{a}$ Twenty-five plants were inoculated with $P$. sclerotioides at 20 days of age and placed outside for one winter exposure period. The following spring, percent mortality was calculated and roots were observed for lesions and pycnidia.

${ }^{\mathrm{b}}$ Ps $(+)=$ pycnidia observed microscopically on roots that were characteristic of those produced by $P$. sclerotioides; Ps $(-)=$ no lesions or pycnidia observed.

${ }^{c}$ TRF, Thief River Falls isolate; RLF, Red Lake Falls isolate; FF, Fergus Falls isolate.

by the endpoint assay is approximately 10,000 copies, making the real-time assay more sensitive by several orders of magnitude. Low to moderate amounts of the fungus were detected in roots of plants surveyed in 2005 that lacked typical BRR symptoms. This is further evidence that the fungus can be detected in alfalfa roots before disease symptoms occur. The realtime assay identified nine additional counties with alfalfa plants harboring low to moderate amounts of the fungus. The realtime PCR assay will be useful in future studies to assess population density of the fungus in soil to establish a threshold level of the fungus for causing disease, for identifying environmental conditions conducive to pathogen survival and increase, and to determine potential rotational crops that reduce pathogen density in soil.

\section{ACKNOWLEDGMENTS}

We gratefully acknowledge the 72 people who contributed plant samples to the surveys. This research was funded in part by the Minnesota Rapid Response Fund from the Minnesota Agricultural Experiment Station. This paper is a joint contribution from the Plant Science Research Unit, USDA-ARS, and the Minnesota Agricultural Experiment Station. Mention of a trademark, proprietary product, or vendor does not constitute a guarantee or warranty of the product by the USDA, and does not imply its approval to the exclusion of other products and vendors that might also be suitable.

\section{LITERATURE CITED}

1. Davidson, J. G. N. 1990. Brown root rot. Pages 29-31 in: Compendium of Alfalfa Diseases. 2nd ed. D. L. Stuteville and D. C. Erwin, eds. American Phytopathological Society, St. Paul, MN.

2. Gachon, C., Mingam, A., and Charrier, B. 2004. Real-time PCR: What relevance to plant studies? J. Exp. Bot. 55:1445-1454.

3. Gray, F. A., Heald, T. E., Hollingsworth, C. R., and Koch, D. W. 1997. Brown root rot caused by Phoma sclerotioides, a new disease of alfalfa in the U.S. Pages 22-24 in: Proc. Western Alfalfa Improv. Conf., 10th.

4. Hollingsworth, C. R. 1999. Biology and management of brown root rot, Phoma sclerotioides, of alfalfa. M.S. thesis. University of Wyoming, Laramie.

5. Hollingsworth, C. R. 2002. Assessing heritability of brown root rot (Phoma sclerotioides) resistance and forage yield in nine alfalfa (Medicago sativa ssp. sativa) populations. Ph.D. diss. University of Wyoming, Laramie.

6. Hollingsworth, C. R., Gray, F. A., and Groose, R. W. 2005. Evidence for the heritability of resistance to brown root rot of alfalfa, caused by Phoma sclerotioides. Can. J. Plant Pathol. 27:64-70.

7. Hollingsworth, C. R., Gray, F. A., Groose, R. W., Koch, D. W., and Heald, T. E. 2001. Development of a protocol for identifying alfalfa, Medicago sativa ssp. sativa reaction to infection by Phoma sclerotioides, causal organism of brown root rot. (Abstr.) Phytopathology 91:S184.

8. Hollingsworth, C. R., Gray, F. A., Groose, R. W., and Mims, C. W. 2002. Morphological responses of Canadian and U.S.A. isolates of Phoma sclerotioides to different growth media, temperatures and light. Mycotaxon 81:331339.

9. Hollingsworth, C. R., Gray, F. A., Koch, D. W., Groose, R. W., and Heald T. E. 2003. Distribution of Phoma sclerotioides and incidence of 
brown root rot of alfalfa in Wyoming, U.S.A. Can. J. Plant Pathol. 25:215-217.

10. Hollingsworth, C. R., Gray, F. A., Koch, D. W., and Heald T. E. 1999. Brown root rot, Phoma sclerotioides, a new challenge for alfalfa growers. Pages 13-15 in: Proc. Western Alfalfa Improv. Conf., 11th.

11. Larsen, R. C., Grau, C. R., Vandemark, G. J., Hughes, T. J., and Hudelson, B. D. 2004. First report of brown root rot of alfalfa caused by Phoma sclerotioides in Wisconsin. Plant Dis. 88:769.

12. Larsen, R. C., Hollingsworth, C. R., Vandemark, G. J., Gritsenko, M. A., and Gray, F. A. 2002. A rapid method using PCR-based SCAR markers for the detection and identification of Phoma sclerotioides: The cause of brown root rot disease of alfalfa. Plant Dis. 86:928-932.

13. Lievens, B., and Thomma, B. P. H. J. 2005. Recent developments in pathogen detection ar- rays: Implications for fungal plant pathogens and use in practice. Phytopathology 95:13741380.

14. McCartney, H. A., Foster, S. J., Fraaije, B. A., and Ward, E. 2003. Molecular diagnostics for fungal plant pathogens. Pest Manag. Sci. 59:129-142.

15. Mikkelson, M. B. 1997. Summary of plant diseases diagnosed on commercial and yard and garden plants in 1996. Montana State University, Cooperative Extension Service, Plant Disease Clinic Report.

16. Samac, D. A., and Hollingsworth, C. R. 2005. Identification of Phoma sclerotioides, the causal agent of brown root rot in Wisconsin and Minnesota. Proc. NAAIC Trifolium Conf., 39th. Quebec City, Quebec, CN.

17. Sanford, G. B. 1933. A root rot of sweet clover and related crops caused by Plenodomus meliloti. Dearness and Sanford. Can. J. Res.
Sect. C. 8:337-348

18. Smith, J. D. 1987. Winter-hardiness and overwintering diseases of amenity turfgrasses with special reference to the Canadian Prairies. Tech. Bull. 1987-12F. Agric. Can. Res. Stn Saskatoon, Saskatchewan.

19. Tsukamoto, J. T. 1965. Phenotypic characteristics of alfalfa tolerant to brown root rot. Can. J. Plant Sci. 45:197-198.

20. White, T. J., Bruns, T., Lee, S., and Taylor, J. 1990. Amplification and direct sequencing of fungal ribosomal RNA genes for phylogenetics. Pages 315-322 in: PCR Protocols: A Guide to Methods and Applications. M. A. Innis, D. H. Gelfand, J. J. Sninsky, and T. J. White, eds. Academic Press, San Diego, CA.

21. Wiersma, J. J., Durgan, B. R., Hollingsworth C. R., MacRae, I. V., and Rehm, G. 2006. Winter Wheat in Minnesota. 12 Pages. UM Ext. Bull. Ag-MI-08421. 